\title{
Assessment of the achieving educational outcomes on summer internships at the first cycle degree programme in Public Health
}

\author{
Joanna Gotlib', Ilona Cieślak', Lucyna Iwanow', Mariusz Jaworski', Mariusz Panczyk¹ \\ ${ }^{1}$ Department of Didactics and Learning Effects, Faculty of Health Sciences, Medical University, Warsaw, Poland \\ Gotlib J, Cieślak I, Iwanow L, Jaworski M, Panczyk M. Assessment of the achieving educational outcomes on summer internships at the first \\ cycle degree programme in Public Health. Med. Og Nauk Zdr. 2019; 25(1): 55-61. doi:10.26444/monz/105456
}

\begin{abstract}
Introduction. Summer internship constitutes one of the key elements in the curriculum. Practical classes at the Medical University of Warsaw that are obligatory for students usually take place during summer internship. The main aim of all internship programmes is to familiarise students with the organisational structure of a particular unit, its tasks, forms of employment and working methods as well as to help employees with their office and administration functions.

Objective. To analyse the effect of assessment of summer internship on students' self-assessment and opinion on achieving educational outcomes at the first cycle degree programme in Public Health.

Materials and method. A total of 85 graduates ( 3 males) of the first-cycle degree programme in Public Health took part in the study. The study enrolled students who had graduated from the first-cycle degree programme in the academic year of 2015-2016. Mean age of the study population amounted to 23.02 years (min. 21; max. 27; SD 7.220). An original anonymous and voluntary questionnaire based on the list of educational outcomes Sefault significance level was established at 0.05 .

Results. According to most study participants, although their summer internships constituted a valuable experience, they did not influence the level of achievement of educational outcomes set in the curriculum for the first cycle degree programme in Public Health.

Conclusion. It is important to continue the assessment of summer internship, verify summer internship sites and develop a database.
\end{abstract}

\section{Key words}

public health, summer internships, educational outcomes

\section{INTRODUCTION}

Summer internship constitutes one of the key elements in the curriculum that plays a significant role in preparing students to enter the labour market. The future career very often depends on the site of internship. Numerous studies on the career development of students have demonstrated that students are offered employment following the internship. The quality of summer internship is of particular importance in the case of the general academic profile, where this is usually the only opportunity for students to have practical classes during the entire course of study $[1,2]$.

The programme in Public Health in Poland is of a general academic profile, which means that students are not obliged to attend practical classes during the academic year, and they mostly attend lectures, seminar and classes in classrooms taught by academic teachers (contact hours) [3].

Depending on the curriculum specified by the list of educational outcomes, the first-cycle degree programme may include practical classes, but they are not mandatory regarding accreditation of the learning programme for Public Health. Given the importance of practical training of students, while granting accreditation to a faculty unit offering training, the Polish Accreditation Committee recommends enabling students to acquire knowledge, skills, and social competence in practice [4].

Practical classes at the Medical University of Warsaw that are obligatory for students usually take place during summer internship. Undergraduate students (first-cycle degree) are obliged to have 160 hours of practical training after the first and second years of study. Students have their internships in the summer months (July, August and September). It is also possible to have an internship during the academic year, as long as it does not conflict with compulsory classes. Students are free to select the site of internship. The scope of internship is specified in an internship referral issued by the Dean's Office. It is recommended that internships

- take place in a hospital department after the first year of the first-cycle programme;

- take place in a healthcare institution, teaching hospital, sanitary and epidemiological station or insurance company after the second year of the first-cycle programme.

The main aim of all internship programs is to familiarise the students with the organisational structure of a particular unit, its tasks, forms of employment and working methods, as well as to help employees with their office and administration functions [5]. 


\section{OBJECTIVE}

The study aimed to analyse the effect of assessment of summer internship on students' self-assessment and opinion on achieving educational outcomes at the first cycle degree programme in Public Health.

\section{MATERIALS AND METHOD}

The study involved a total of 85 graduates ( 3 males) of the first-cycle degree programme in Public Health at the Division of Public Health, Faculty of Health Sciences, Warsaw Medical University. The study enrolled students who had graduated from the first-cycle degree programme in the academic year 2015-2016 (course of study in 2013-2016, only $50 \%$ of students enrolled for the first year of the firstcycle degree programme graduated from the course: 85 out of 167 students). Questionnaire return rate was 97\% (85/87). Mean age of the study population amounted to 23.02 years (min. 21; max. 27; SD 7.220). Unmarried persons constituted a vast majority of the study group ( $97 \%, 76$ persons), married persons amounted to $3 \%$ of the total ( 2 persons).

In line with the position of the Ethical Review Board of Warsaw Medical University, approval of the Board is not necessary to conduct retrospective studies, surveys, and other non-invasive research [6].

A voluntary questionnaire study was conducted between July-September 2016. Students filled-in the questionnaire after graduation while receiving the certificate evidencing completion of the programme in the Dean's Office, in a dedicated site, in order to preserve anonymity. The time required for filling-in the questionnaire was about 15 minutes.

The original anonymous questionnaire used in the study was developed in the Division of Teaching and Outcomes of Education, Faculty of Health Sciences, Warsaw Medical University, based on the list of educational outcomes established by the resolution of Warsaw Medical University Senate and existing curricula in the Division of Public Health, Faculty of Health Sciences, Warsaw Medical University.

There were three parts to the questionnaire. The first part aimed to discover what students think about the level of achievement of particular educational outcomes during the first-cycle degree programme in Public Health. This part of the questionnaire comprised a total of 72 statements divided into three domains: knowledge (29 statements), skills (30 statements), and social competence (13 statements). Students rated the level of achievement of educational outcomes during the course of study on a five-point Likert scale, with 1 referring to "Strongly disagree" and 5 to "Strongly agree." The second part of the questionnaire concerned the self-assessment of students with respect to particular educational outcomes for the first-cycle degree programme in Public Health. Similar to the first one, this part of the questionnaire comprised a total of 72 statements divided into three domains: knowledge (29 statements), skills (30 statements), and social competence (13 statements). Students rated the level of achievement of educational outcomes on a five-point Likert scale, with 1 referring to "Strongly disagree" and 5 to "Strongly agree."

In addition, educational outcomes in the fields of knowledge and skills were divided in accordance with the division included in the main chapters of ASPHER's list of European Public Health Core Competences [7] (Tab. 1).
Table 1. Educational outcomes divided into areas of knowledge that are of key importance according to Public Health students

\begin{tabular}{llcc}
\hline \multirow{2}{*}{ Area } & \multicolumn{2}{c}{$\begin{array}{c}\text { Number of } \\
\text { educational outcomes }\end{array}$} \\
\cline { 2 - 4 } & $\begin{array}{c}\text { Knowledge } \\
\text { (29 state- } \\
\text { ments) }\end{array}$ & $\begin{array}{c}\text { Skills (30 } \\
\text { state- } \\
\text { ments) }\end{array}$ \\
\hline Methods in public health & 4 & 3 \\
\hline Population health and socio-economic determinants & 4 & 4 \\
\hline $\begin{array}{l}\text { Population health and its material - physical, } \\
\text { radiological, chemical and biological -environmental } \\
\text { determinants }\end{array}$ & 4 & 1 \\
\hline $\begin{array}{l}\text { Health policy; economics; organizational theory and } \\
\text { management }\end{array}$ & 11 & 9 \\
\hline $\begin{array}{l}\text { Health promotion: health education, health protection } \\
\text { and disease prevention }\end{array}$ & 2 & 3 \\
\hline Ethics & 4 & 2 \\
\hline Other & - & 8 \\
\hline
\end{tabular}

Source: [7]

The third part of the questionnaire comprised 19 questions about summer internship, career plans, and continuation of studies after obtaining the Bachelor's degree in the Division of Public Health, Faculty of Health Sciences, Warsaw Medical University.

Statistical analysis. A contingency Table analysis was used to determine the relationship between the assessment of internship undertaken during the course of studies and the achievement of educational outcomes and graduates' selfassessment of competencies. A non-parametric Spearman coefficient of rank correlation (rho-Spearman) was applied for the analysis due to the formal nature of variables whose correlations were assessed [8]. Coefficient values range between -1 and +1 . The value of zero refers to the independence of variables and is achieved if the difference between each pair of ranks equals zero. The closer to -1 or +1 the coefficient is, the stronger the correlation [9]. All calculations were performed using STATISTICA version 13.1 (StatSoft $^{\circledR}$ ) in compliance with the license of Warsaw Medical University. The default significance level was established at 0.05.

\section{RESULTS}

Most students participating in the study stated that although their internships had been valuable, they had not influenced the level of achievement of educational outcomes set in the curriculum for the first-cycle degree programme in Public Health (Tab. 2, Tab. 3).

In the case of 10 statements concerning knowledge, internships had significantly influenced the opinion of

Table 2. General assessment of summer internships among second-cycle degree students of Public Health

\begin{tabular}{lcccc}
\hline Assessment of internships & Mean & Median & SD \\
\hline $\begin{array}{l}\text { Do you perceive your summer internship as valuable? } \\
\text { Do you believe that your internship helped to achieve } \\
\begin{array}{l}\text { educational outcomes set in the curriculum for the } \\
\text { first-cycle degree programme in Public Health? }\end{array}\end{array}$ & 4 & 0 & 28 \\
\hline
\end{tabular}

Source: Based on own results 
Table 3. Detailed assessment of summer internships among second-cycle degree students of Public Health

\begin{tabular}{lcccc}
\hline Assessment & $\begin{array}{c}\text { Do you perceive your } \\
\text { summer internship as } \\
\text { valuable? }\end{array}$ & $\begin{array}{c}\text { Do you believe that your internship } \\
\text { helped to achieve educational } \\
\text { outcomes set in the curriculum for } \\
\text { the first-cycle degree programme in } \\
\text { Public Health? }\end{array}$ \\
\cline { 2 - 6 } & $\mathrm{n}$ & $\%$ & $\mathrm{n}$ & $\%$ \\
\hline Strongly no (1) & 13 & 5 & 21 & 6 \\
\hline No (2) & 23 & 1 & 30 & 0 \\
\hline No opinion (3) & 2 & 5 & 7 & 9 \\
\hline Yes (4) & 28 & 4 & 15 & 6 \\
\hline Strongly yes (5) & 13 & 5 & 6 & 0 \\
\hline Source Bas & & & & \\
\hline
\end{tabular}

Source: Based on own results

students participating in the study on the achievement of educational outcomes related to the area of knowledge. Better assessment of internship went hand-in-hand with better assessment of the achievement of educational outcomes at WMU, and better self-assessment of competencies [all significant correlations $(\mathrm{p}<0.05)$ were positive].

Table 4 presentsa detailed opinions of students on the effect of internships on self-assessment and achievement of educational outcomes in the area of knowledge with respect to the curriculum for the first-cycle degree programme in Public Health.

Table 5 shows detailed opinions of students on the effect of internship on self-assessment and achievement of educational outcomes in the area of skills with respect to the curriculum for the first-cycle degree programme in Public Health.

Table 6 gives detailed opinions of students on the effect of internship on self-assessment and achievement of educational outcomes in the area of social competence with respect to the curriculum for the first-cycle degree programme in Public Health.

\section{DISCUSSION}

The obtained results concerning opinions of first-cycle students of Public Health at the Division of Public Health, Faculty of Health Sciences, WMU, demonstrated the necessity to modify the curriculum for the first-cycle degree programme and verify the expectations of institutions offering internships, due to an insufficient level of achievement of educational outcomes during internships.

Just over a half of the respondents (51\%) considered that their summer internships had not helped in achieving the educational outcomes set in the curriculum. The authors believe that this may be indicative of two phenomena: on the one hand, there is a risk that staff of institutions offering internship positions to Public Health students are not aware of what skills and competences interns have, and hence tasks assigned to them are not appropriate to their level of education. On the other hand, the fact that educational outcomes are not achieved during summer internships may result from the fact that the curriculum fails to meet expectations of employers. In this event, it appears appropriate to establish a system facilitating a smooth exchange of information between a university-level school offering a programme in Public Health and employers in order to set priorities in training specialists in public health.
Assessment of internships regarding achievement of educational outcomes and self-assessment of students relating to their skills and knowledge. Students participating in the study positively assessed the impact of summer internships on the achievement of educational outcomes and self-assessment of competencies in the case of 10 out of 29 outcomes of education in the domain referring to knowledge. According to the present authors, this shows that the quality of internships taken by students is relatively poor, which hampers the use of knowledge acquired by students in a practical manner. This may be caused either by the lack of substantive preparation of the respondents to carry out their tasks, or their little involvement in internships, or ignorance of employers about competencies of their interns. It is positive that during their internships, students improved their knowledge relating to major-related areas for public health, such as legal, economic, and organisational operation of the healthcare system in Poland.

In the case of the domain related to skills, the study group assessed positively the influence of internships on only one educational outcome: "A student applies in practice legal provisions influencing human health activities." This is particularly worrying since the main emphasis during internships should be placed on the development of skills. Internships constitute one of the few possibilities during the entire course of studies for students to put knowledge into practice. The obtained results may confirm that in the present curriculum there are too few classes during which activating methods are used, enabling students to develop skills crucial for prospective employers and prepare them for internships, as well as for their future practice.

Assessment of internships regarding achievement of educational outcomes and self-assessment of students relating to their social competence. The present study also aimed to analyse the opinion of students on the implementation of the learning content related to the development of social competence of graduates during internships, and their self-assessment in that regard. Only in the case of two competencies: "Effectively presents his/ her own ideas, doubts, and suggestions, with adequate reasoning and in accordance with ethical principles" and "Recognises the importance of continuing education and taking care of his/her own health and that of others", the respondents positively assessed the impact of internships. This is in line with the opinion of employers, who highlighted the lack of team work, communication, negotiation, and problem-solving skills, as well as the lack of creativity among Public Health students [10]. Internships should ensure that students can develop and improve their social skills which are increasingly taken into account during recruitment for a post related to public health.

The presented results indicate the need for change with respect to summer internships and modification of the curriculum for Public Health. At the Medical University of Warsaw, there is no database of internship sites available to all students. Additionally, there is no agreement between institutions offering internship positions and the university with respect to requirements placed on students during the internship. The level of achievement of educational outcomes during internships mandatory for public health students is not studied in Poland. Therefore, it is interesting to look at solutions adopted in other countries. For example, 
Table 4. Opinions of students on the effect of internship on self-assessment and achievement of educational outcomes in the area of knowledge with respect to the curriculum for the first cycle degree programme in Public Health

\begin{tabular}{|c|c|c|c|c|c|c|c|c|}
\hline & \multicolumn{4}{|c|}{ Internships were valuable } & \multicolumn{4}{|c|}{$\begin{array}{l}\text { Internships helped in achieving } \\
\text { educational outcomes }\end{array}$} \\
\hline & \multicolumn{2}{|c|}{$\begin{array}{c}\text { Achievement } \\
\text { of educational } \\
\text { outcomes }\end{array}$} & \multicolumn{2}{|c|}{$\begin{array}{l}\text { Student self- } \\
\text { assessment }\end{array}$} & \multicolumn{2}{|c|}{$\begin{array}{c}\text { Achievement } \\
\text { of educational } \\
\text { outcomes }\end{array}$} & \multicolumn{2}{|c|}{$\begin{array}{l}\text { Student self- } \\
\text { assessment }\end{array}$} \\
\hline & $\begin{array}{l}\text { Spearman's } \\
\text { Rho }\end{array}$ & $\mathrm{p}$ & $\begin{array}{l}\text { Spearman's } \\
\text { Rho }\end{array}$ & $\mathrm{p}$ & $\begin{array}{l}\text { Spearman's } \\
\text { Rho }\end{array}$ & $\mathrm{p}$ & $\begin{array}{l}\text { Spearman's } \\
\text { Rho }\end{array}$ & $\mathrm{p}$ \\
\hline \multicolumn{9}{|l|}{ Methods in public health* } \\
\hline $\begin{array}{l}\text { Has a background knowledge of theory and methodology of developing a strategy } \\
\text { for health and social programmes. }\end{array}$ & 14 & 234 & -0.01 & 900 & 09 & 420 & 06 & 629 \\
\hline Defines quantitative and qualitative methods of social research. & 07 & 550 & -0.05 & 677 & 00 & 987 & 08 & 496 \\
\hline Describes methods used for the quality assurance and assessment in healthcare. & 24 & 032 & 04 & 704 & 15 & 179 & 19 & 096 \\
\hline $\begin{array}{l}\text { Describes information and IT centres and systems used for analyses related to } \\
\text { public health. }\end{array}$ & 24 & 032 & 01 & 920 & 24 & 033 & 01 & 932 \\
\hline \multicolumn{9}{|l|}{ Population health and its socio-economic determinants } \\
\hline Defines basic concepts describing the health status of the population. & 10 & 403 & -0.01 & 898 & 18 & 111 & 10 & 394 \\
\hline Describes methods used for defining healthcare needs of the population. & -0.03 & 796 & 02 & 892 & 16 & 162 & 20 & 071 \\
\hline $\begin{array}{l}\text { Presents main health hazards and problems of the Polish population, including } \\
\text { local communities. }\end{array}$ & -0.04 & 735 & 05 & 693 & 06 & 617 & 17 & 140 \\
\hline $\begin{array}{l}\text { Presents national and international sources of information and population health } \\
\text { monitoring systems. }\end{array}$ & 16 & 162 & -0.02 & 831 & -0.01 & 957 & 04 & 741 \\
\hline
\end{tabular}

\section{Population health and its material—physical, radiological, chemical and biological—environmental determinants}

\begin{tabular}{|c|c|c|c|c|c|c|c|c|}
\hline Defines the impact of behavioural and environmental factors on the health status. & 04 & 714 & 02 & 872 & 06 & 627 & 07 & 522 \\
\hline $\begin{array}{l}\text { Correctly interprets the existing relationships between health and work } \\
\text { environment. }\end{array}$ & 20 & 076 & 07 & 558 & 10 & 369 & 20 & 074 \\
\hline $\begin{array}{l}\text { Describes biological processes in the human body as well as the structure and } \\
\text { function of particular systems and organs in a healthy and ill body. }\end{array}$ & 23 & 044 & 11 & 333 & 11 & 333 & 05 & 635 \\
\hline $\begin{array}{l}\text { Has a general knowledge of etiopathogenesis, diagnostics, and treatment } \\
\text { methods for selected diseases, especially those of particular social importance. }\end{array}$ & 24 & 037 & 02 & 894 & 11 & 327 & 08 & 486 \\
\hline \multicolumn{9}{|l|}{ Health policy; economics; organizational theory and management } \\
\hline $\begin{array}{l}\text { Enumerates the guidelines for the economic evaluation of healthcare } \\
\text { programmes. }\end{array}$ & 26 & 020 & 05 & 644 & 29 & 010 & 23 & 045 \\
\hline $\begin{array}{l}\text { Defines economic determinants of the operation of health system and healthcare } \\
\text { facilities. }\end{array}$ & 32 & 004 & 22 & 047 & 10 & 396 & 19 & 098 \\
\hline Explains the impact of economic incentives on human behaviour & 26 & 020 & 08 & 462 & 20 & 083 & 11 & 340 \\
\hline Describes functions of the main organisational structures in healthcare. & 09 & 432 & 19 & 096 & 11 & 327 & 13 & 260 \\
\hline $\begin{array}{l}\text { Presents guidelines on cooperation with local authorities and other entities } \\
\text { competent in the area of social prevention. }\end{array}$ & 10 & 372 & -0.04 & 706 & -0.05 & 657 & 14 & 223 \\
\hline Lists all elements of social security and health insurance systems. & 17 & 131 & 04 & 746 & 17 & 124 & 12 & 296 \\
\hline $\begin{array}{l}\text { Describes organisational and legal aspects of the operation of the Polish } \\
\text { healthcare system. }\end{array}$ & 20 & 080 & 04 & 733 & 27 & 016 & 03 & 820 \\
\hline $\begin{array}{l}\text { Presents the principles and directions of the healthcare system reform in Poland, } \\
\text { including legal and financial issues. }\end{array}$ & 10 & 374 & 17 & 144 & 08 & 495 & 26 & 022 \\
\hline $\begin{array}{l}\text { Defines legal and financial basis for providing medical services and implementing } \\
\text { health programmes. }\end{array}$ & 23 & 042 & 23 & 044 & 16 & 157 & 25 & 024 \\
\hline Presents the basic concepts related to social communication. & 22 & 052 & 22 & 049 & 16 & 170 & 25 & 028 \\
\hline Describes procedures in the event of a natural disaster. & 07 & 540 & 02 & 878 & 14 & 221 & 25 & 028 \\
\hline
\end{tabular}

Health promotion: health education, health protection and disease prevention

Defines concepts related to health and lifestyle.

$\begin{array}{llllllll}06 & 581 & 17 & 130 & 12 & 283 & 26 & 021\end{array}$

Defines strategies used at various levels of prevention and health promotion activities.

$\begin{array}{llllllll}03 & 789 & -0.06 & 573 & 13 & 250 & 21 & 057\end{array}$

\section{Ethics}

\begin{tabular}{|c|c|c|c|c|c|c|c|c|}
\hline $\begin{array}{l}\text { Discusses legal provisions regulating the protection of patients> rights and rules of } \\
\text { professional ethics, with particular reference to medical professions. }\end{array}$ & 21 & 065 & -0.04 & 717 & 08 & 490 & 07 & 512 \\
\hline $\begin{array}{l}\text { Presents the basic legal principles for providing assistance to the socially excluded } \\
\text { and victims of violence, for social reintegration, etc. }\end{array}$ & 16 & 153 & 10 & 366 & 04 & 753 & 22 & 049 \\
\hline Defines intellectual property protection rules and copyrights. & 18 & 115 & 00 & 967 & -0.02 & 833 & 01 & 936 \\
\hline $\begin{array}{l}\text { Specifies the legal effects of the basic procedural requirements in administrative } \\
\text { law. }\end{array}$ & 18 & 114 & -0.11 & 348 & 12 & 294 & 03 & 791 \\
\hline
\end{tabular}


Table 5. Opinions of students on the effect of internship on self-assessment and achievement of educational outcomes in the area of skills with respect to the curriculum for the first-cycle degree programme in Public Health

\begin{tabular}{|c|c|c|c|c|c|c|c|c|}
\hline & \multicolumn{4}{|c|}{ Internships were valuable } & \multicolumn{4}{|c|}{$\begin{array}{l}\text { Internships helped in achieving } \\
\text { educational outcomes }\end{array}$} \\
\hline & \multicolumn{2}{|c|}{$\begin{array}{l}\text { Achievement } \\
\text { of educational } \\
\text { outcomes }\end{array}$} & \multicolumn{2}{|c|}{$\begin{array}{l}\text { Student self- } \\
\text { assessment }\end{array}$} & \multicolumn{2}{|c|}{$\begin{array}{l}\text { Achievement } \\
\text { of educational } \\
\text { outcomes }\end{array}$} & \multicolumn{2}{|c|}{$\begin{array}{l}\text { Student self- } \\
\text { assessment }\end{array}$} \\
\hline & $\begin{array}{l}\text { Spearman's } \\
\text { Rho }\end{array}$ & $\mathrm{p}$ & $\begin{array}{l}\text { Spearman's } \\
\text { Rho }\end{array}$ & $\mathrm{p}$ & $\begin{array}{l}\text { Spearman's } \\
\text { Rho }\end{array}$ & $\mathrm{p}$ & $\begin{array}{l}\text { Spearman's } \\
\text { Rho }\end{array}$ & $\mathrm{p}$ \\
\hline \multicolumn{9}{|l|}{ Methods in public health ${ }^{* * *}$} \\
\hline Processes epidemiological data using simple statistical and analytical tools. & 11 & 314 & 14 & 217 & 15 & 183 & 19 & 093 \\
\hline $\begin{array}{l}\text { Finds relevant information in scientific literature, databases and other sources } \\
\text { related to health. }\end{array}$ & 07 & 511 & 02 & 871 & -0.01 & 926 & -0.04 & 744 \\
\hline Develops a prevention programme compliant with methodology. & 05 & 657 & -0.09 & 431 & 10 & 401 & -0.10 & 368 \\
\hline \multicolumn{9}{|l|}{ Population health and its social and economic determinants } \\
\hline $\begin{array}{l}\text { Uses indicators of health status to analyse the health status of the population and } \\
\text { define population health problems. }\end{array}$ & 10 & 402 & 08 & 463 & 10 & 389 & 14 & 210 \\
\hline $\begin{array}{l}\text { Diagnoses and indicates problems of critical importance for public health in } \\
\text { individual social spheres. }\end{array}$ & 02 & 870 & 20 & 078 & 15 & 196 & 16 & 170 \\
\hline $\begin{array}{l}\text { Analyses the determinants of health situation in the context of social and } \\
\text { demographic processes. }\end{array}$ & 16 & 150 & 05 & 643 & 06 & 607 & 04 & 746 \\
\hline $\begin{array}{l}\text { Has the ability to cooperate with the media, local community and non- } \\
\text { governmental organisations in implementing health-related activities. }\end{array}$ & -0.05 & 688 & -0.01 & 919 & 01 & 913 & 00 & 991 \\
\hline \multicolumn{9}{|c|}{ Population health and its material_-physical, radiological, chemical and biological_environmental determinants } \\
\hline Identifies environmental threats to human health. & 13 & 269 & 18 & 123 & 12 & 308 & 14 & 211 \\
\hline \multicolumn{9}{|l|}{ Health policy; economics; organizational theory and management } \\
\hline Identifies factors influencing state health policy. & 02 & 896 & -0.03 & 807 & 11 & 347 & 07 & 542 \\
\hline Categorises basic costs of health units. & 25 & 029 & 20 & 078 & 14 & 211 & 15 & 181 \\
\hline $\begin{array}{l}\text { Makes a use of results of analyses for specific (alternative) solutions in the } \\
\text { healthcare sector. }\end{array}$ & 13 & 271 & -0.06 & 582 & 20 & 084 & 06 & 618 \\
\hline Analyses selected determinants of health and social problems. & 14 & 213 & 09 & 405 & -0.02 & 872 & 05 & 661 \\
\hline $\begin{array}{l}\text { Differentiates the types of contracts to provide health services between payers and } \\
\text { healthcare providers. }\end{array}$ & 14 & 235 & 09 & 425 & 08 & 462 & 07 & 541 \\
\hline Applies in practice legal provisions influencing human health activities. & 07 & 529 & 07 & 532 & 21 & 065 & 25 & 024 \\
\hline $\begin{array}{l}\text { Identifies political processes and defines their impact on health problems and } \\
\text { problems of the health sector. }\end{array}$ & 11 & 354 & 11 & 334 & 11 & 348 & 15 & 191 \\
\hline $\begin{array}{l}\text { Draws conclusions based on observation of the basic economic phenomena in } \\
\text { micro and macro scales. }\end{array}$ & 01 & 938 & 11 & 332 & -0.08 & 474 & 05 & 672 \\
\hline $\begin{array}{l}\text { Makes a use of information on institutions forming the system for monitoring } \\
\text { of risks and on methods used for transferring data and information to those } \\
\text { institutions }\end{array}$ & 11 & 342 & 06 & 572 & 13 & 267 & 22 & 057 \\
\hline \multicolumn{9}{|l|}{ Health promotion: health education, health protection and disease prevention } \\
\hline Presents and evaluates different health promotion concepts and models. & -0.07 & 527 & -0.02 & 831 & -0.02 & 888 & 03 & 773 \\
\hline $\begin{array}{l}\text { Participates in the development and introduction of local projects and actions in } \\
\text { the field of public health. }\end{array}$ & 11 & 347 & -0.04 & 740 & 02 & 838 & 15 & 186 \\
\hline $\begin{array}{l}\text { Makes a use of epidemiological and socio-medical studies to evaluate health } \\
\text { needs and expectations of patients. }\end{array}$ & -0.05 & 635 & 15 & 177 & 09 & 412 & 21 & 065 \\
\hline \multicolumn{9}{|l|}{ Ethics } \\
\hline Formulates opinions on social issues. & 09 & 451 & 01 & 950 & 10 & 362 & 11 & 355 \\
\hline $\begin{array}{l}\text { Applies the provisions relating to copyrights and protection of databases used in } \\
\text { daily work of healthcare entities. }\end{array}$ & -0.03 & 792 & 14 & 210 & 06 & 581 & 16 & 147 \\
\hline \multicolumn{9}{|l|}{ Others } \\
\hline $\begin{array}{l}\text { Uses methods and techniques learned during the course to solve particular } \\
\text { communication problems }\end{array}$ & 16 & 161 & 13 & 258 & 18 & 110 & 19 & 095 \\
\hline $\begin{array}{l}\text { When working in groups, uses interpersonal knowledge acquired during the } \\
\text { course. }\end{array}$ & 29 & 011 & 03 & 780 & 20 & 073 & 19 & 090 \\
\hline Improves the effectiveness of his/her interactions with others. & 22 & 051 & 06 & 573 & 16 & 169 & 15 & 199 \\
\hline Draws conclusions based on theoretical knowledge. & 19 & 103 & 14 & 204 & 14 & 224 & 16 & 169 \\
\hline Justifies the need for changing the strategy or priorities. & 17 & 134 & -0.02 & 896 & 19 & 104 & -0.01 & 913 \\
\hline $\begin{array}{l}\text { Expresses his/her knowledge orally and in writing (e.g. by delivering presentations) } \\
\text { at the academic level. }\end{array}$ & 30 & 007 & -0.06 & 586 & 17 & 123 & -0.05 & 657 \\
\hline Works in a team taking different roles. & 15 & 183 & 07 & 535 & 10 & 403 & 12 & 281 \\
\hline $\begin{array}{l}\text { Speaks a foreign language - can understand the main points of complex text on } \\
\text { both concrete and abstract topics, including public health discussions }\end{array}$ & 19 & 092 & 18 & 108 & 10 & 377 & 06 & 585 \\
\hline
\end{tabular}

Source: Based on own results. 
Table 6. Opinions of students on the effect of internship on self-assessment and achievement of educational outcomes in the area of social competence with respect to the curriculum for the first-cycle degree programme in Public Health

\begin{tabular}{|c|c|c|c|c|c|c|c|c|}
\hline & \multicolumn{4}{|c|}{ Internships were valuable } & \multicolumn{4}{|c|}{$\begin{array}{l}\text { Internships helped in achieving } \\
\text { educational outcomes }\end{array}$} \\
\hline & \multicolumn{2}{|c|}{$\begin{array}{l}\text { Achievement } \\
\text { of educational } \\
\text { outcomes }\end{array}$} & \multicolumn{2}{|c|}{ Self-assessment } & \multicolumn{2}{|c|}{$\begin{array}{l}\text { Achievement } \\
\text { of educational } \\
\text { outcomes }\end{array}$} & \multicolumn{2}{|c|}{ Self-assessment } \\
\hline & $\begin{array}{l}\text { Spearman's } \\
\text { Rho }\end{array}$ & $\mathrm{p}$ & $\begin{array}{l}\text { Spearman's } \\
\text { Rho }\end{array}$ & $\mathrm{p}$ & $\begin{array}{l}\text { Spearman's } \\
\text { Rho }\end{array}$ & $\mathrm{p}$ & $\begin{array}{l}\text { Spearman's } \\
\text { Rho }\end{array}$ & $\mathrm{p}$ \\
\hline $\begin{array}{l}\text { Recognises problems which are outside the scope of his/her competence } \\
\text { and knows who to ask for help, including the ability to cooperate within an } \\
\text { interdisciplinary team. }\end{array}$ & 22 & 054 & 02 & 852 & 12 & 309 & 08 & 510 \\
\hline Feels responsible for local community problems. & 01 & 960 & -0.02 & 847 & 12 & 308 & 18 & 114 \\
\hline Respects patients/clients and understands their difficulties. & 17 & 141 & 02 & 831 & 15 & 191 & 03 & 781 \\
\hline $\begin{array}{l}\text { Initiates the development and introduction of local projects and actions in the } \\
\text { field of public health. }\end{array}$ & -0.05 & 656 & -0.01 & 901 & -0.09 & 412 & -0.04 & 703 \\
\hline Manages time effectively. & 11 & 330 & 11 & 318 & 02 & 876 & 05 & 661 \\
\hline Disseminates knowledge of goals and tasks of public health. & 12 & 310 & 00 & 997 & 12 & 303 & 06 & 611 \\
\hline $\begin{array}{l}\text { Properly designs and performs professional tasks following the health and safety } \\
\text { regulations. }\end{array}$ & 10 & 359 & 14 & 227 & 09 & 433 & 18 & 119 \\
\hline $\begin{array}{l}\text { Is independent and critical in improving his/her knowledge and skills, including } \\
\text { the interdisciplinary context. }\end{array}$ & 21 & .062 & 09 & 456 & 07 & 550 & 08 & 470 \\
\hline $\begin{array}{l}\text { Is tolerant and open towards different opinions and attitudes shaped by various } \\
\text { social and cultural factors. }\end{array}$ & 22 & .057 & 08 & 488 & 14 & 219 & -0.05 & 693 \\
\hline $\begin{array}{l}\text { Effectively presents his/her own ideas, doubts, and suggestions, with adequate } \\
\text { reasoning and in accordance with ethical principles. }\end{array}$ & 22 & .050 & 20 & 076 & 14 & 211 & 24 & 034 \\
\hline $\begin{array}{l}\text { Appreciates actions aiming at the prevention of occupational stress and its } \\
\text { negative effects. }\end{array}$ & 15 & .183 & 09 & 435 & 18 & 121 & 18 & 105 \\
\hline $\begin{array}{l}\text { Recognises the importance of continuing education and taking care of his/her own } \\
\text { health and that of others. }\end{array}$ & 12 & .310 & 06 & 621 & 07 & 523 & 24 & 031 \\
\hline
\end{tabular}

Source: Based on own results

professional internships in the major of Public Health at Maastricht University in the Netherlands are based on a programme included in the timetable. Internships are compulsory, and the course is related to diploma projects of particular students. A list of institutions offering internship positions is presented by the university every year. They mostly include European public health institutions, government agencies, insurance companies, consulting agencies, research institutes and faculties of particular universities [11].

Horney and Davis from the University of North Carolina Center for Public Health Preparedness in the USA, discussed another example of how internships are supposed to look. In 2003, they established Team Epi-Aid whose aim was to organise voluntary-based internships in cooperation with State and local institutions dealing with the management of outbreaks of diseases or other urgent situations. Evaluation of internships in 2010 demonstrated that students participating in initiatives within internship programmes were more often able to find a job in their profession, and had the chance to use in practice the knowledge acquired during the course of studies [12].

A programme based on similar principles is also in effect in the United Kingdom. It includes public universities offering training in public health across the country, and involves their cooperation with the National Health Service (NHS). Abilities in analysing and assessing scientific evidence, creating policies and strategies for health, as well as leadership and cooperation between institutions, are considered to be the key competences of graduating students [13].
The "TRIUMPH" (Training in Urban Medicine and Public Health) programe in the USA may serve as the last example of an efficient use of internships. The programme aims to integrate the professional practice of students of medicine and public health in epidemiological research, mentoring projects, and developing guidelines for public health [14]. Such a combination gives public health students an opportunity to fully use the interdisciplinarity of their major.

\section{CONCLUSION}

Most study participants stated that although their summer internships had been valuable, they had not helped in achieving educational outcomes set in the curriculum for the first-cycle degree programme in Public Health, and they had not had a significant influence on the students' selfassessment. It is important to continue the assessment of summer internships, verify summer internship sites, and develop a database.

\section{Ethical considerations}

Ethical issues (including plagiarism, informed consent, misconduct, data fabrication and/or falsification, double publication and/or submission, redundancy, etc.) have been strictly observed by the authors. 


\section{REFERENCES}

1. Narayanan VK, Olk PM, Fukami CV. Determinants of Internship Effectiveness: An Exploratory Model. ACAD MANAG LEARN EDU 2010; 9:61-80

2. Templeton W, Updyke K, Bennett J, Robert B Internships and the Assessment of Student Learning. BEA 2012; 4:27-38.

3. Kasyanova S. The education system in Poland in the framework of Bologna Process. Education and Management 2005; 8: 3-4.

4. The polish Accreditation Committee [World Wide Web]. Warsaw; [cited 2 January 2018]. Available from: http://www.pka.edu.pl/rodzaje-ocen/.

5. Faculty of Health Sciences, Medical University of Warsaw [World Wide Web]. Warsaw: wnoz; [cited 2 January 2018]. Available from: https://wnoz.wum.edu.pl/content/ksztalcenie-na-kierunku-zdrowiepubliczne.

6. Opinion of the Bioethical Commission of the Medical University of Warsaw http://komisja-bioetyczna.wum.edu.pl/ content/szczeg\%C3\%B3\%C5\%82owe-informacje-oraz-wzorydokument $\% \mathrm{C} 3 \% \mathrm{~B} 3 \mathrm{w}$.

7.Foldspang A (ed.) (2007). Provisional Lists of public health Core Competencies. European Public Health Core Competencies Programme
(EPHCC) for Public Health Education. Phase 1. ASPHER Series No. 2. Brussels: ASPHER.

8.Brzezińska J (2015). Analiza logarytmiczno-liniowa: teoria i zastosowania $\mathrm{z}$ wykorzystaniem programu R. Wydawnictwo $\mathrm{CH}$ Beck.

9.Stanisz, A (2006). Przystępny kurs statystyki. Tom 1. Statystyki podstawowe. Statsoft. Kraków.

10. Bjegovic-Mikanovic V, Czabanowska K, Flahault A, Otok R, Shortell S, Wisbaum W, Laaser U. Addressing needs in the public health workforce in Europe. World Health Organization 2014.

11. Kupier T, Meijer A, Moust J. Innovation in Public Health Teaching. The Maastricht Experience. Public Health Reviews 2011; 33(1):300-314.

12. Horney JA, Davis MK, Ricchetti-Masterson KL, MacDonald PD. Fueling the public health workforce pipeline through student surge capacity response teams. Journal of Community Health 2004; 39(1): 35-39.

13. Wright J, Rao M, Walker K. The UK Public Health Skills and Career Framework-Could it help to make public health the business of every workforce? Journal of The Royal Institute of Public Health 2008; 122: 541-544.

14. Haq C, Stearns M, Brill J, Crouse B, Foertsch J, Konx K, Stearns J, Skochelak S, Golden RN. Training in Urban Medicine and Public Health: TRIUMPH. Acad Med 2013; 88(3): 352-363.

\title{
Ocena realizacji efektów kształcenia dotyczących praktyk wakacyjnych na studiach I stopnia na kierunku Zdrowie Publiczne
}

\begin{abstract}
I Streszczenie
Wstęp. Praktyki wakacyjne stanowią jeden z kluczowych elementów programu nauczania. Obowiązkowe dla studentów zajęcia praktyczne w Warszawskim Uniwersytecie Medycznym są zwykle realizowane podczas praktyk wakacyjnych. Głównym celem wszystkich praktyk jest zapoznanie studenta ze strukturą organizacyjną jednostki, zadaniami, formami oraz metodami pracy.

Cel pracy. Celem pracy była analiza wpływu oceny praktyk wakacyjnych na samoocenę oraz opinie studentów na temat realizacji efektów kształcenia na studiach I stopnia na kierunku Zdrowie Publiczne.

Materiał i metoda. W badaniach udział wzięło 85 absolwentów (3 mężczyzn i 82 kobiety) studiów I stopnia na kierunku Zdrowie Publiczne w Oddziale Zdrowia Publicznego Wydziału Nauki o Zdrowiu Warszawskiego Uniwersytetu Medycznego. Badaniami objęto absolwentów, którzy ukończyli studia I stopnia w roku akademickim 2015/2016. Średnia wieku w badanej grupie studentów wyniosła 23,02 lat (min. 21; max. 27; SD 7,220). Studenci wypełniali ankiety po ukończeniu studiów, w czasie odbioru dokumentów potwierdzających ukończenie studiów w Dziekanacie. Do badań wykorzystano autorski, anonimowy i dobrowolny kwestionariusz ankiety skonstruowany w Zakładzie Dydaktyki i Efektów Kształcenia Wydziału Nauki o Zdrowiu Warszawskiego Uniwersytetu Medycznego, oparty na liście efektów kształcenia ogłoszonych Uchwałą Senatu WUM. Jako domyślny poziom istotności statycznej przyjęto wartość 0,05 .

Wyniki. W badanej grupie studentów większość osób deklarowała, że odbyte praktyki były wartościowe, ale jednocześnie nie wpłynęły one na poziom realizacji efektów kształcenia zawartych w programie studiów I stopnia na kierunku Zdrowie Publiczne.

Wniosek. Należy zatem kontynuować ocenę praktyk wakacyjnych, zweryfikować miejsca praktyk wakacyjnych i zbudować bazę.
\end{abstract}

\section{Słowa kluczowe}

zdrowie publiczne, praktyki wakacyjne, efekty kształcenia 